\title{
Screening and characterization of amylase and cellulase activities in psychrotolerant yeasts
}

\author{
Mario Carrasco, Pablo Villarreal, Salvador Barahona, Jennifer Alcaíno, Víctor Cifuentes and Marcelo Baeza*
}

\begin{abstract}
Background: Amylases and cellulases have great potential for application in industries such as food, detergent, laundry, textile, baking and biofuels. A common requirement in these fields is to reduce the temperatures of the processes, leading to a continuous search for microorganisms that secrete cold-active amylases and cellulases. Psychrotolerant yeasts are good candidates because they inhabit cold-environments. In this work, we analyzed the ability of yeasts isolated from the Antarctic region to grow on starch or carboxymethylcellulose, and their potential extracellular amylases and cellulases.

Result: All tested yeasts were able to grow with soluble starch or carboxymethylcellulose as the sole carbon source; however, not all of them produced ethanol by fermentation of these carbon sources. For the majority of the yeast species, the extracellular amylase or cellulase activity was higher when cultured in medium supplemented with glucose rather than with soluble starch or carboxymethylcellulose. Additionally, higher amylase activities were observed when tested at pH 5.4 and 6.2 , and at $30-37{ }^{\circ} \mathrm{C}$, except for Rhodotorula glacialis that showed elevated activity at $10-22{ }^{\circ} \mathrm{C}$. In general, cellulase activity was high until pH 6.2 and between $22-37{ }^{\circ} \mathrm{C}$, while the sample from Mrakia blollopis showed high activity at $4-22^{\circ} \mathrm{C}$. Peptide mass fingerprinting analysis of a potential amylase from Tetracladium sp. of about $70 \mathrm{kDa}$, showed several peptides with positive matches with glucoamylases from other fungi.

Conclusions: Almost all yeast species showed extracellular amylase or cellulase activity, and an inducing effect by the respective substrate was observed in a minor number of yeasts. These enzymatic activities were higher at $30{ }^{\circ} \mathrm{C}$ in most yeast, with highest amylase and cellulase activity in Tetracladium sp. and M. gelida, respectively. However, Rh. glacialis and $\mathrm{M}$. blollopis displayed high amylase or cellulase activity, respectively, under $22^{\circ} \mathrm{C}$. In this sense, these yeasts are interesting candidates for industrial processes that require lower temperatures.
\end{abstract}

Keywords: Amylase, Cellulase, Cold-active enzymes, Psychrotolerant yeasts

\section{Background}

Yeasts inhabit almost all environments on the earth including cold environments in which they are permanently exposed to temperatures below $5{ }^{\circ} \mathrm{C}$. These coldadapted yeasts are classified as psychrophilic if their optimum and maximum temperatures for growth are $\leq$ $15{ }^{\circ} \mathrm{C}$ and $\leq 20{ }^{\circ} \mathrm{C}$, respectively, or as psychrotolerant (psychrotrophic) if their maximum temperature for growth is above $20{ }^{\circ} \mathrm{C}[1,2]$. An adaptation of yeasts to

\footnotetext{
* Correspondence: mbaeza@u.uchile.cl

Departamento de Ciencias Ecológicas, Facultad de Ciencias, Universidad de Chile, Las Palmeras 3425, Casilla 653, Santiago, Chile
}

cold is the production of extracellular hydrolytic enzymes to use the available carbon sources and in this way they contribute to nutrient recycling and organic matter mineralization $[3,4]$. The main adaptation of enzymes from psychrophiles is the maximization of their flexibility resulting in a slower decrease of the reaction rate when temperature is decreased in contrast to their mesophile or thermophile counterparts [5]. Psychrophilic enzymes have higher enzymatic activities at lower temperatures than their mesophyll equivalents [6] and a reduced thermal stability to counteract freezing [7]. These features have attracted the attention of many scientists in recent years due their potential for application 
in industry. The production of cold-active enzymes including amylase, lipase, protease, cellulase, pectinase and esterase has been reported in yeast species and generally the properties of yeast enzymes differ from those produced by other microorganisms $[8,9]$. Cold active amylases and cellulases have great potential to be applied in processes that may require low temperatures such as those in the food, biofuels and detergents industries $[10,11]$. Amylolytic enzymes are comprised of three main sub-groups: $\alpha$-amylase, $\beta$-amylase and glucoamylase [12, 13]. Although all of these enzymes are able to hydrolyze $\alpha$-glucosidic bonds in starch, they have structural and catalytic differences [14]. The complete degradation of raw starch is fundamental to the microbial industrial production of biofuels, and is currently accomplished by supplementation of $\alpha$-amylase and glucoamylase during the fermentative processes [15].

Cellulases are responsible for the hydrolysis of cellulose to sugars in the environment, and cellulose is the largest source of renewable energy on the planet [16]. Cellulases are produced by bacteria and fungi [17-19], and these enzymes are useful in food industry, environmental remediation, fuel production and particularly in the laundry industry [16]. The most commonly used cellulases in industry are produced by fungi, which have optimum temperature at $50{ }^{\circ} \mathrm{C}$ [20]. Although cellulases from some psychrophilic yeasts have been described, within cold active enzymes, cellulases remain less studied [21].

To achieve a cost-effective process and to avoid the production of undesirable by-products generated at higher temperatures, a current research effort is aimed at searching for microorganisms that secrete amylases or cellulases that are active at lower temperatures. These microorganisms are even more appealing if they use economical culture media containing raw starch or cellulose as the main constituents [22-25]. Previously, our group isolated yeasts from soil samples from the sub-Antarctic region belonging to 22 species, and in preliminary assays several of them showed amylase and cellulase activities, respectively [26]. In this work, these yeasts were further characterized with respect to their assimilation and fermentation of soluble starch (SS) and carboxymethylcellulose (CMC). The enzymatic activities in extracellular protein samples obtained from yeasts cultivated in different media were evaluated at different $\mathrm{pH}$ and temperatures. Protein samples from yeast species with major amylase or cellulase activities were fractioned by ammonium sulfate precipitation and the protein fractions having the activity of interest were analyzed by peptide mass fingerprint, obtaining promising results.

\section{Results and discussion}

\section{Growth and fermentation assays}

Yeasts that previously showed positive results for amylase and cellulase activities in colony assays were analyzed for their ability to grow in minimal media (YNB) with SS or CMC as the sole carbon source. As shown in Fig. 1, all tested yeasts were able to grow on these media. In media supplemented with SS, the majority of yeast species produced more biomass at $2 \%$ than at lower concentrations, except Cryptococcus gilvescens and $R h$.

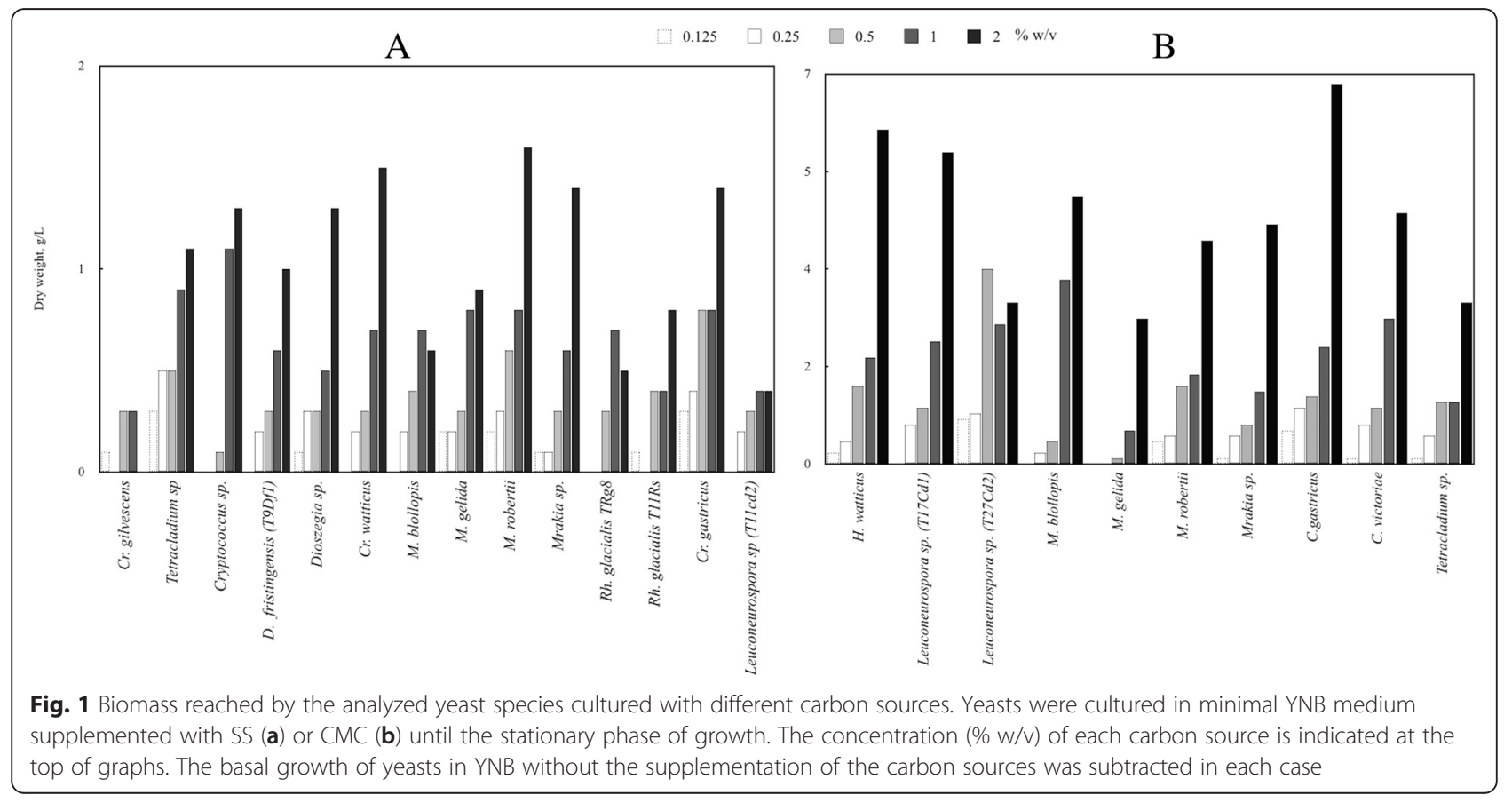


glacialis B19 that reached a higher biomass when cultured with $0.5-1$ and $1 \%$ of SS, respectively (Fig. 1a). With the exception of Leuconeurospora sp. (T27Cd2), which reached more biomass when cultured with $0.5 \%$ $\mathrm{CMC}$, all yeasts showed a higher biomass when cultured with $2 \% \mathrm{CMC}$ than with lower concentrations. The ability of the yeast to perform alcoholic fermentation using both compounds as carbon sources was evaluated by the Durham method and ethanol quantification in liquid cultures, but negative results were obtained for all yeast species (not shown). In the case of glucose, positive results were obtained for Candida sake, Mrakia blollopis, Mrakia gelida, Mrakia robertii and Wickermanomyces anomalus. Due to an increase in the viscosity of the medium, the maximum concentration of SS or CMC that could be added to culture media was $2 \%$, so it was not possible to test higher concentrations. It is important to mention that a significant decrease of the medium viscosity was observed concomitantly with yeast growth. Taken together, these results suggest that the analyzed yeast species are able to assimilate SS and/or CMC, but they are not able to ferment these compounds.

\section{Enzyme activities of extracellular protein samples}

Total secreted proteins were obtained by ammonium sulfate precipitation from supernatants from yeast cultures using YM medium supplemented with glucose, and enzyme activities in the samples were evaluated by well test assays. In all assays, denaturalized protein controls corresponding to the protein sample incubated at $100{ }^{\circ} \mathrm{C}$ for 15 min were included and in all cases, no activity was observed, as shown in well 2 from Fig. 2a. As exemplified in Fig. 2, a high amylase activity was observed in D. fristingensis (T9) samples and a lower activity was observed in samples from Leuconeurospora sp. T11cd2 cultures (Fig. 2a). Le. fragaria and Mrakia $s p$. culture samples showed higher cellulase activities (Fig. 2b). In addition, enzyme activities of the protein samples were tested at different $\mathrm{pH}$ and temperature conditions including $\mathrm{pH} 4.6,5.4$ and 6.2; and 4, 10, $15,22,30$ and $37{ }^{\circ} \mathrm{C}$. The protein samples from the majority of the yeasts analyzed had higher amylase activities at pH 5.4 and 6.2 , and at 30 and $37^{\circ} \mathrm{C}$ (Fig. 3a). The highest amylase activities were observed in protein samples from Dioszegia fristingensis (T9Df1), M. blollopis, Holtermaniella watticus and Tetracladium sp., which were higher at pH 6.2 and $37^{\circ} \mathrm{C}$. No amylase activity was observed in samples from Cryptococcus sp. and Cr. gilvescens. Cellulase activity could not be assayed at $\mathrm{pH} 4.6$ because the medium in the agar-plates did not solidify at this $\mathrm{pH}$. As shown in Fig. 3b, the highest cellulase activity was observed in samples from Leuconeurospora T17Cd1 at $\mathrm{pH} 6.2$ and $22-30{ }^{\circ} \mathrm{C}$. Also, high activities were observed in samples from Mrakia sp. $\left(\mathrm{pH} 5.4 ; 22-30{ }^{\circ} \mathrm{C}\right), \mathrm{M}$. blollopis $\left(\mathrm{pH} 5.4 ; 4-15^{\circ} \mathrm{C}\right.$ ) and Tetracladium sp. $(\mathrm{pH} 5.4$; $30{ }^{\circ} \mathrm{C}$ ). No cellulase activity was observed in samples from Cr. gastricus, $H$. watticus, Leucosporidiella fragaria and Wickermanomyces anomalus in the assayed conditions. In general, the halos observed in the enzyme activity assays had variable degrees of turbidity. However, samples from Tetracladium sp. and M. gelida gave very clear halos in the amylase and cellulase activity assays, respectively, suggesting greater substrate degradation. Although all yeasts were able to grow in medium with SS or CMC as the sole carbon source, the corresponding extracellular enzyme activity was not observed in some of the protein samples as mentioned above. Considering that it has been previously reported that $\mathrm{CMC}$ has an inducing effect in the cellulase activity from the fungus Ganoderma applanatum MR-56 [27] and that amylolytic activity was induced by SS in bacterial isolates [28], it is possible that the yeasts tested in this work require the presence of the substrate to induce

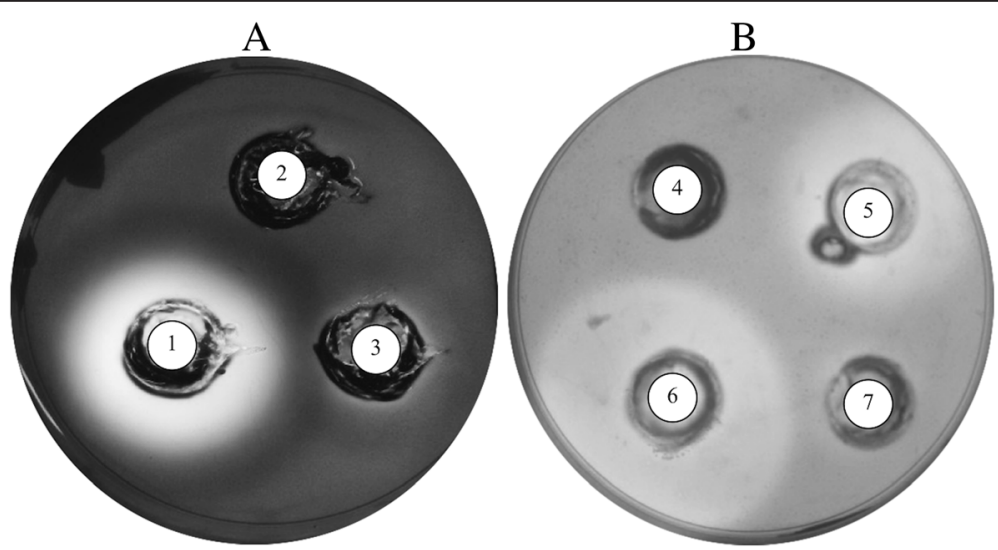

Fig. 2 Enzymatic activities determined by well test assays. Extracellular protein samples were deposited into wells generated in the plates to analyze amylase (a) or cellulase (b) activities, which were incubated at $15^{\circ} \mathrm{C}$. Protein samples in wells: $1, D$. fristingensis (T9Df1); $2, D$. fristingensis (T9Df1) inactivated at $100{ }^{\circ} \mathrm{C}$ for $15 \mathrm{~min} ; 3$, Leuconeurospora sp.; 4, Cr. gastricus; 5, D. fristingensis (T11Df1); 6, L. fragaria; 7, W. anomalus 


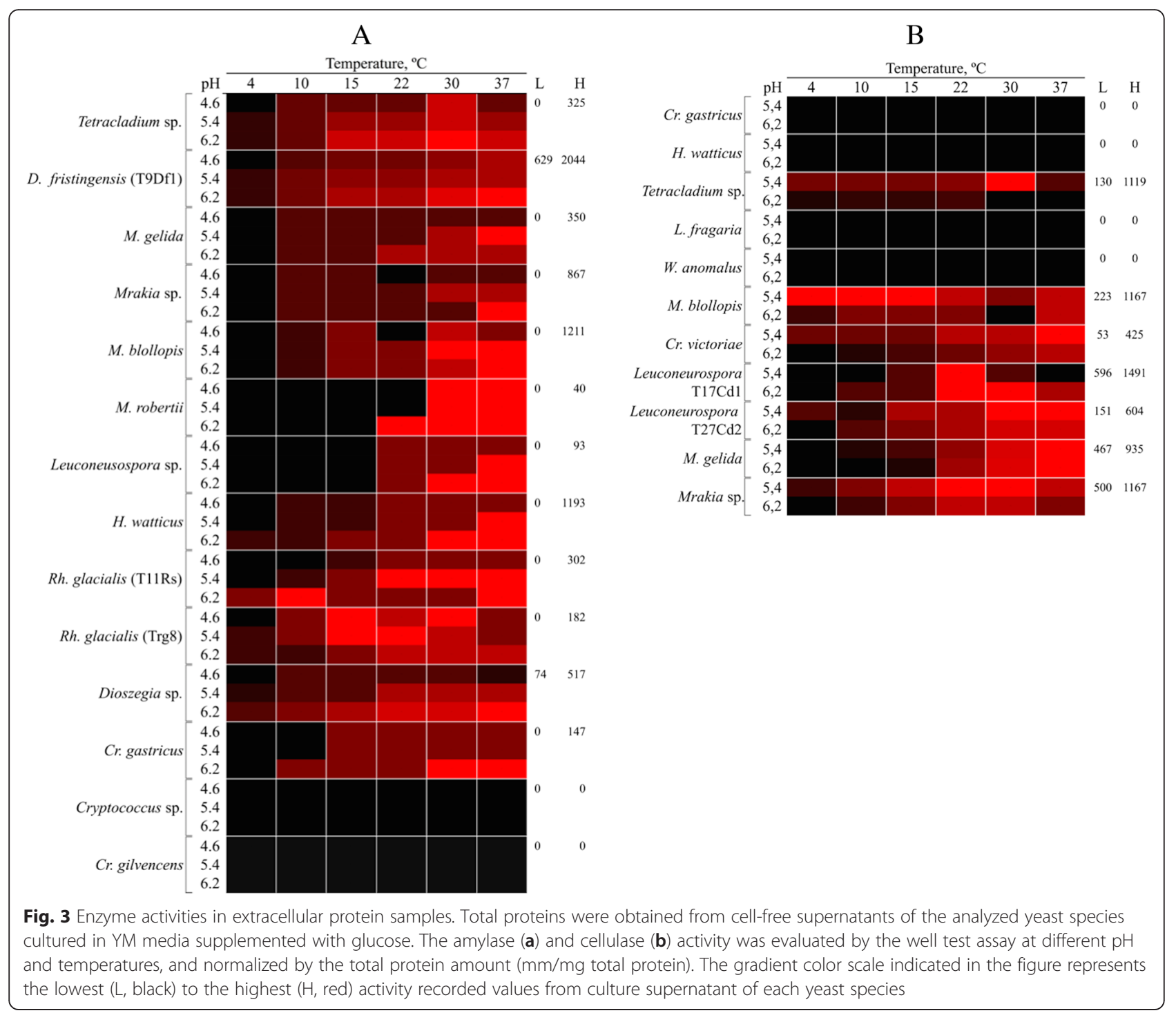

the expression of the corresponding genes that encode the respective enzyme activity. To evaluate this possibility, the yeasts were cultured in YM medium supplemented with SS or CMC, the extracellular proteins were obtained and the activities measured (Additional file 1). Figure 4 shows the enzyme activities of protein samples from yeast cultivated in medium supplemented with glucose, SS or CMC, at the $\mathrm{pH}$ and temperature at which the highest activity was observed in each case. An amylase activity inducing effect by SS was observed only in samples obtained from four yeast species, most notably in $C r$. gilvescens and $M$. robertii (Fig. 4a). In the other species, the amylase activity was higher in samples from yeast cultivated in medium supplemented with glucose; even more for $H$. watticus, Rh. glacialis T8Rg and Rh. glacialis T11Rg, no amylase activity was detected when the yeasts were grown in media supplemented with SS. For Cryptococcus sp., no amylase activity was observed in the protein samples obtained from cultures in both conditions. In the analyses of cellulase activities, an inductor effect by $\mathrm{CMC}$ was observed only in samples from Cr. gastricus, $\mathrm{H}$. watticus and Le. fragaria, whereas in the samples from the other yeasts species, the highest cellulase activities were observed when yeasts were cultivated in medium supplemented with glucose (Fig. 4b). No cellulase activity was observed in samples from $W$. anomalus grown in either condition. As indicated in each column of Fig. 4, for almost all yeast species, the total protein amounts were higher in samples from cultures supplemented with SS or CMC than with glucose; however, this increase in total protein content was not correlated with an increase of either amylase or cellulase activity in the samples. Although Cryptococcus $s p$. and $W$. anomalus were able to grow using SS and $\mathrm{CMC}$ as the sole carbon source, and amylase and cellulase activities were previously detected in yeast colony assays, neither activity was detected in extracellular protein 


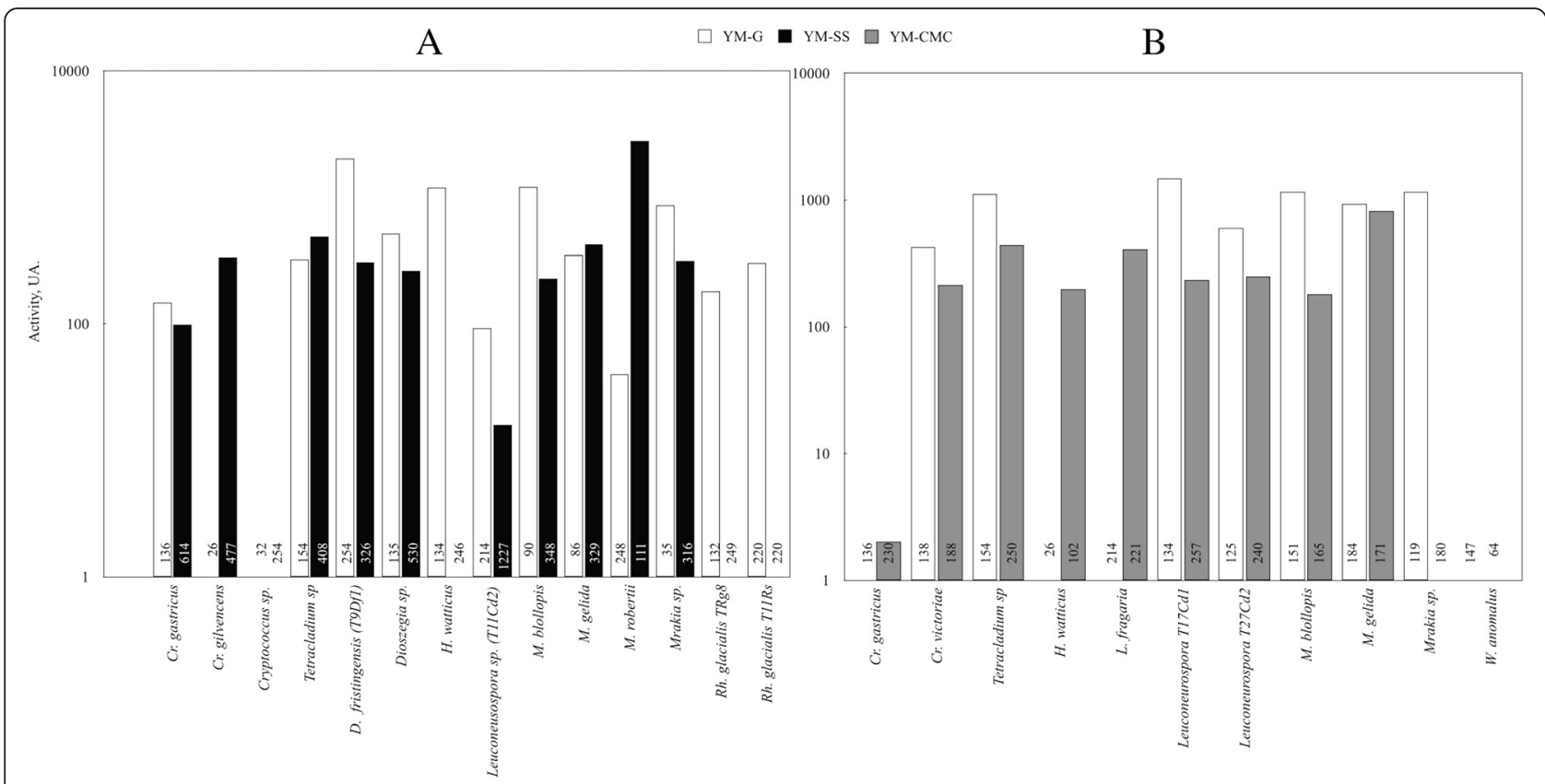

Fig. 4 Comparison of extracellular enzymatic activities. Protein samples were obtained from yeast cultures in YM medium supplemented with glucose (YM-G), SS (YM-SS) or CMC (YM-CMC). The amylase (a) and cellulase (b) activities were evaluated and normalized by total protein amount $(\mu \mathrm{g})$ used in the assays, which is indicated in each column

samples from yeast cultures in either condition. It is possible that the corresponding enzymes are anchored to the cell wall, as this has been described for amylase-like enzymes in two species of Aspergillus [29, 30]. There is limited data regarding amylase activity in the yeast genera described in this work; amylase activity was described in Cryptococcus sp. [31] and Cr. flavus [32], the latter of which was successfully expressed in S. cerevisiae [33], Mrakia blollopis [34], Rhodotorula svalbardensis sp. nov [35] and Tetracladium setigerum [36]. No reported data were found in literature about amylase activity in the genera Dioszegia, Leuconeurospora and Holtermaniella. Cellulase activity has been described in Cryptococcus laurentii and Cryptococcus nemorosus [37], Tetracladium [36], and in Mrakia species isolated from Arctic puddles [38]. No data were found in the literature regarding cellulase activity for the genera Dioszegia, Leuconeurospora, Leucosporidiella and Wickermamomyces. The yeast studied in this work were originally isolated from soil samples of King George Island [26] in which there is a considerable input of organic materials, including vegetation. Furthermore, the temperatures in this region are warmer than the rest of Antarctica, having seasonal changes and that can reach up to $20^{\circ} \mathrm{C}$ in summer [26, 39-41]. According to this, the yeasts studied that showed extracellular cellulase and amylase activities, can use the complex carbon sources, suggesting an active role in vegetable residues recycling and mineralization in this cold environment. Furthermore, the amylase and cellulase activities were detected in a wide range of temperature $\left(4\right.$ to $\left.30^{\circ} \mathrm{C}\right)$ and the majority showed higher activities at moderate temperatures $\left(22\right.$ or $\left.30{ }^{\circ} \mathrm{C}\right)$. However, these temperatures are lower than those described for these enzymes in mesophilic organisms, which generally show optimal activities at temperatures over $40{ }^{\circ} \mathrm{C}[42,43]$. This last point reflects the adaptations of the yeasts studied here to the conditions of the subAntarctic region where they thrive.

\section{Identification of proteins}

Taking into account that currently the industrial production of biofuels is accomplished by supplementation of amylases during the fermentative processes, which is mainly carried out by $S$. cerevisiae [15], it is desirable that the used enzymes have high activity at temperatures near to $30{ }^{\circ} \mathrm{C}$. This was the case of Tetracladium sp. and M. gelida for amylase and cellulase activity, respectively, so they were selected for further analyses. The yeast Tetracladium $s p$. was cultured in liquid YM media supplemented with glucose or SS, and the extracellular proteins were fractionated by precipitation with ammonium sulfate (20 to $80 \%$ ). Amylase activity was determined in each fraction, revealing that the fraction obtained with $60 \%$ of ammonium sulfate had the highest activity, so this condition was used for the subsequent analyses. Protein samples obtained from cultures supplemented with glucose or SS (Fig. 5a) had a main protein band of 


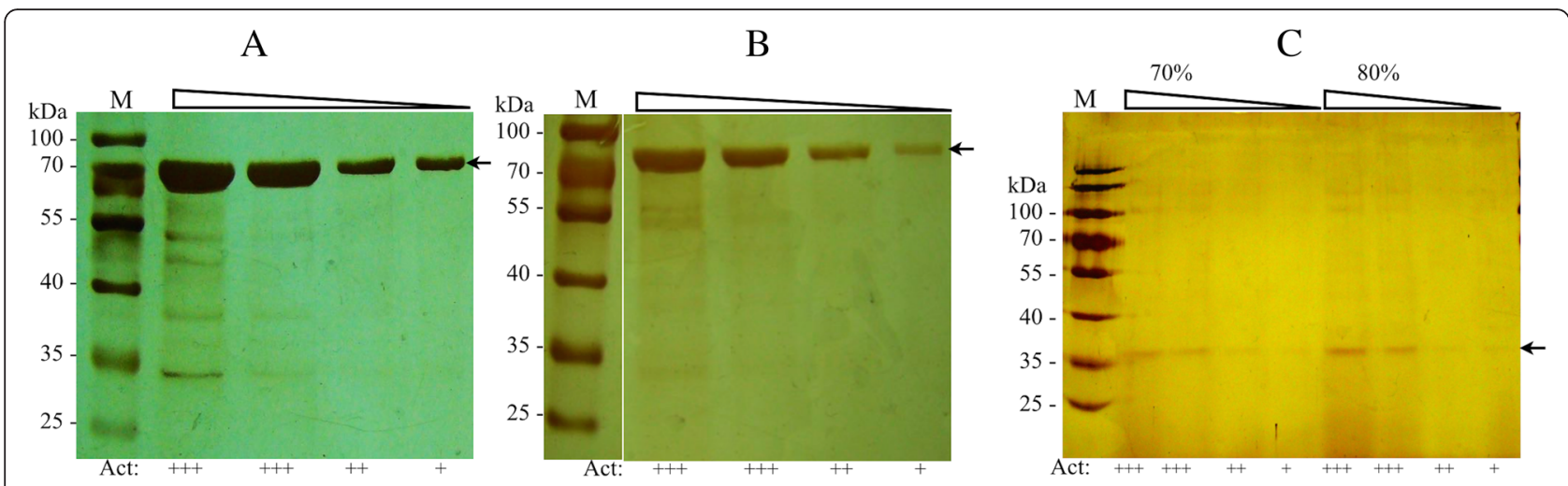

Fig. 5 Extracellular proteins analysis by SDS-PAGE. Proteins samples were obtained from yeast cultures of Tetracladium sp. (a and $\mathbf{b})$ and M. gelida (c) in YM medium supplemented with glucose (a and c) or soluble starch (b). Samples were fractioned with ammonium sulfate. The $60 \%$ fraction, which had the highest amylase activity (a and $\mathbf{b}$ ), and the 70 and $80 \%$ fractions (c) that had the highest cellulase activity are shown. Serial dilutions of the samples were made (indicated at the top of gels) and the degree of the determined amylase or cellulase activity by the well assay is indicated at the bottom of each gel lane as follows: highest $(+++)$ and lowest $(+)$ recorded activity. The arrows indicate the protein band associated to amylase (a and b) or cellulase activity (c). M, protein marker

about $70 \mathrm{kDa}$, which after serial dilutions was the only band observed in SDS-PAGE concomitantly with amylase activity. Similar analysis was performed for the yeast M. gelida that showed cellulase activity, which was detected in the fractions of 70 and $80 \%$ of ammonium sulfate from cultures supplemented with glucose and CMC. In analyses of samples from cultures with glucose, a main protein band of about $36 \mathrm{kDa}$ was observed in samples with cellulase activity (Fig. 5b). Although we made several attempts to characterize the extracellular proteins from M. gelida grown in the presence of CMC, the quality of these results was always poor. As in previously reported results [44], this may be due to remaining $C M C$ in the culture supernatant that interfered with the precipitation of proteins and SDSPAGE analysis protocols, despite performing extensive dialysis of samples. The described 70 and $36 \mathrm{kDa}$ protein bands were analyzed by peptide mass fingerprinting, and the results were analyzed using the Mascot search engine. In the case of the probable cellulase protein, no significant matches were found in the database. For the probable amylase protein, several peptides matched completely with fungal glucoamylases whose sizes ranged from 58 to $68 \mathrm{kDa}$, which is in accordance with the calculated size of the protein band mentioned above. The peptides ALVEGSTFA SKVGASCSWCDSQAPQVLCFLQR, GSSFFTIAVQHR, CDSQAPQVLCFLQR, QAPQVLCFLQR and APQVLCFL $\mathrm{QR}$, matched with glucoamylase precursor protein (XP_001213553) of Aspergillus terreus (NIH2624); the peptide DAALTMK with glucoamylase (ENH88038) of Colletotrichum orbiculare MAFF 240422; the peptides DAALTMK and SQAVIQTANNPSGSLLPSGLGLGEAK with glucoamylase (XP_007284956) of Colletotrichum gloeosporioides
Nara gc5; and peptides DAALTMK and FNGAWGRPQR with glucoamylase (GAK68551) of Pseudozyma antarctica.

\section{Conclusions}

All yeast species analyzed in this work showed the ability to assimilate SS or CMC, but none of them was able to carry out ethanol fermentation of these compounds. Relatively few yeast species showed an inducing effect of SS or CMC in the production of amylase or cellulase activity, respectively. For the majority of the analyzed yeast species, the two enzyme activities were higher when the culture medium was supplemented with glucose than with the corresponding substrate. The higher amylase activity values were obtained at $\mathrm{pH} 5.4$ and 6.2; and at 30 and $37{ }^{\circ} \mathrm{C}$, except for $R h$. glacialis isolates, which showed high amylase activity at lower temperatures $\left(10-22{ }^{\circ} \mathrm{C}\right)$. In general, the cellulase activity was high at $\mathrm{pH}$ values until 6.2 and from $22-37{ }^{\circ} \mathrm{C}$; however, samples from $M$. blollopis showed high activity at lower temperatures $\left(4-22{ }^{\circ} \mathrm{C}\right)$. According to peptide mass fingerprint analysis, the main extracellular protein of approximately $70 \mathrm{kDa}$ in Tetracladium $s p$. culture supernatants with amylase activity indeed corresponds to a glucoamylase.

\section{Methods}

\section{Yeast strains, media and culture conditions}

The yeasts used in this work are listed in Table 1, and were previosly isolated by our group from soil samples of King George Island at the sub-Antarctic region [26]. The yeasts were routinely cultivated in YM medium ( $0.3 \%$ yeast extract, $0.3 \%$ malt extract, $0.5 \%$ peptone) supplemented with $1 \%$ glucose at their optimal temperature of growth and orbital shaking at $150 \mathrm{rpm}$. 
Table 1 Yeast species used in this study

\begin{tabular}{|c|c|c|c|}
\hline Species & Optimal growth $\left({ }^{\circ} \mathrm{C}\right)$ & $\begin{array}{l}\text { Cellulase } \\
\text { activity }\end{array}$ & $\begin{array}{l}\text { Amylase } \\
\text { activity }\end{array}$ \\
\hline Cr. gastricus & 22 & + & + \\
\hline Cr. gilvescens & 22 & - & + \\
\hline Cr. victoiae & 22 & + & - \\
\hline H. watticus & 22 & + & + \\
\hline Cryptococcus sp. & 15 & - & + \\
\hline Dioszegia sp. & 15 & - & + \\
\hline${ }^{a}$ Tetracladium sp. & 22 & + & + \\
\hline D. fristingensis (T9Df1) & 15 & - & + \\
\hline Le. fragaria & 22 & + & - \\
\hline Leuconeurospora sp. (T11Cd2) & 15 & - & + \\
\hline Leuconeurospora sp. (T17Cd1) & 22 & + & - \\
\hline Leuconeurospora sp. (T27Cd2) & 22 & + & - \\
\hline M. blollopis & 15 & + & + \\
\hline M. gelida & 15 & + & + \\
\hline M. robertii & 15 & + & + \\
\hline Mrakia sp. & 15 & + & + \\
\hline Rh. glacialis (TRg8) & 15 & - & + \\
\hline Rh. glacialis (T11Rs) & 15 & - & + \\
\hline W. anomalus & 22 & + & - \\
\hline
\end{tabular}

The indicated enzyme activity reported in previous colony assays [26]. ${ }^{a}$ Formerly $D$. fristingensis (T11Df)

When specific carbon sources SS and CMC were used, these were supplemented to SD medium $(0.1 \%$ yeast nitrogen base, $0.05 \%$ ammonium sulfate). In the case of semi-solid cultures, agar at $1.5 \%$ was added to the medium.

\section{Carbon source assimilation and fermentation tests}

Yeasts were inoculated to reach an initial $\mathrm{OD}_{600}$ of 0.1 in flasks containing YNB medium supplemented with $0.125,0.25,0.5,1$ or $2 \% \mathrm{w} / \mathrm{v}$ of SS or CMC. For each carbon source, $2 \%$ was the maximum concentration that could be used due to an increase in viscosity of the medium. The flasks were incubated at 15 or $22{ }^{\circ} \mathrm{C}$, and the growth was followed by measuring the $\mathrm{OD}_{600}$ of the culture. When the stationary phase was reached, $4 \mathrm{ml}$ of the culture was centrifuged at $10,000 \mathrm{~g}$ for $10 \mathrm{~min}$ to determine the cell dry weight $(\mathrm{CDW})$ of the pellet dried at $100{ }^{\circ} \mathrm{C}$ for $24 \mathrm{~h}$. The fermentation of both carbon sources was evaluated by using Durham test tubes [45] and by quantification of ethanol production using the Ethanol Assay Kit (Megazyme, Wicklow, Ireland) according to manufacturer's instructions. All experiments were carried out in triplicates.
Extraction of extracellular proteins and analysis

Extracellular proteins were obtained by centrifuging $100 \mathrm{ml}$ of yeast cultures at $7,000 \mathrm{~g}$ for $10 \mathrm{~min}$ at $4{ }^{\circ} \mathrm{C}$, and the obtained supernatants were filtered through a sterile $0.45-\mu \mathrm{m}$ pore size polyvinylidene fluoride membrane (Millipore, Billerica, MA, USA). Then, ammonium sulfate was added to reach a final concentration of $80 \%$ saturation and incubated on ice for $1 \mathrm{~h}$ followed by centrifugation at $10,000 \mathrm{~g}$ at $4{ }^{\circ} \mathrm{C}$ for $15 \mathrm{~min}$. The pellet was suspended in $5 \mathrm{ml}$ of Tris buffer $(10 \mathrm{mM}, \mathrm{pH}$ 7.0) and dialyzed against the same buffer using a dialysis bag with a $10-\mathrm{kDa}$ cut off. The total protein content was determined by the Bradford method (Coomassie Protein Assay Kit, Thermo Scientific, IL, USA) and analyzed on a $10 \%$ SDSpolyacrilamide gel electrophoresis (SDS-PAGE) and then stained with silver nitrate (Merck KGaA, Darmstadt, Germany).

\section{Enzyme activity analysis}

Protein samples were deposited into wells cut in YMagar medium supplemented with $1 \%$ of SS or CMC. The $\mathrm{pH}$ of media was adjusted with phosphate-citrate buffer and the plates were incubated at 4, 10, 15, 22, 30 or $37{ }^{\circ} \mathrm{C}$. For amylase activity assays, the plates were flooded with $1 \mathrm{ml}$ of iodine solution and positive activity was defined as a clear halo around the colony on a purple background [46]. For cellulose activity assays, the plates were flooded with $1 \mathrm{mg} / \mathrm{ml}$ of Congo red solution, which was poured off after $15 \mathrm{~min}$ and then the plates were flooded with $1 \mathrm{M} \mathrm{NaCl}$ for $15 \mathrm{~min}$. Positive cellulase activity was defined as a clear halo around the colony on a red background [47]. Enzyme activities were measured as the distance in $\mathrm{mm}$ from the edge of the well to the halo normalized by total amount of protein of the sample.

\section{Peptide mass fingerprinting (PMF)}

Processing and analysis of protein samples were performed at the Central Service for Experimental Research (Valencia, Spain). Samples were digested with sequencing grade trypsin (Madison, WI 53711 USA) as described previously [48]. The digestion reactions were stopped with TFA (1 \% final concentration) and then concentrated to $20 \mu \mathrm{L}$ by speed vacuum to analyze $5 \mu \mathrm{L}$ by liquid chromatography and tandem mass spectrometry (LC-MS/MS). The obtained data were analyzed by Mascot, and only the results with a score greater than $54(P<0.05)$ were considered statistically significant [49].

\section{Availability of supporting data}

All the supporting data are included as additional files. 


\section{Additional file}

\section{Additional file 1: Enzyme activities in yeast extracellular protein} samples. Total proteins were obtained from cell-free supernatants of yeast species grown in YM media supplemented with SS (A) or CMC (B). The amylase (A) or cellulase (B) activity was evaluated by the well test assay at different $\mathrm{pH}$ and temperatures, and normalized by the total protein amount. The color gradient scale represents the degree of amylase activity from each yeast species from the lowest $(L$, black) to the highest $(H$, red) value. (PNG $1298 \mathrm{~kb}$ )

\section{Abbreviations}

CMC: carboxymethyl cellulose; SS: soluble starch.

\section{Competing interests}

The authors declare that they have no competing interests.

\section{Authors' contributions}

$M B$ conceived the study; MC preformed the majority of the experiments; PV and SB participated in protein extractions and analysis; JA, MB and VC participated in the experimental design and analyses. MB, MC, JA and VC drafted the manuscript. All authors read and approved the final manuscript

\section{Acknowledgements}

This study was financially supported through FONDECYT grant 1130333.

\section{Received: 9 June 2015 Accepted: 13 February 2016}

\section{Published online: 19 February 2016}

\section{References}

1. Robinson $\mathrm{CH}$. Cold adaptation in arctic and antarctic fungi. New Phytol. 2001;151:341-53.

2. Gounot AM. Psychrophilic and psychrotrophic microorganisms. Experientia. 1986;42:1192-7

3. Margesin R, Miteva V. Diversity and ecology of psychrophilic microorganisms. Res Microbiol. 2011;162:346-61.

4. Singh $P$, Singh SM. Characterization of yeast and filamentous fungi isolated from cryoconite holes of Svalbard. Arctic Polar Biol. 2012;35:575-83.

5. Cavicchioli R, Charlton T, Ertan H, Omar SM, Siddiqui KS, Williams TJ. Biotechnological uses of enzymes from psychrophiles. Microb Biotechnol. 2011:4:449-60

6. D'Amico S, Claverie P, Collins T, Georlette D, Gratia E, Hoyoux A, et al. Molecular basis of cold adaptation. Philos Trans R Soc Lond B Biol Sci. 2002; 357:917-25.

7. Bjelic S, Brandsdal BO, Aqvist J. Cold adaptation of enzyme reaction rates. Biochemistry. 2008:47:10049-57.

8. Buzzini P, Margesin R. Cold-Adapted Yeasts. In: Białkowska A, Turkiewicz M, editors. Miscellaneous Cold-Active Yeast Enzymes of Industrial Importance. New York: Springer; 2014

9. Shivaji S, Prasad GS. Antarctic Yeasts: Biodiversity and Potential Applications. In: Satyanarayana T, Kunze G, editors. Yeast Biotechnology: Diversity and Applications. Dordrecht: Springer Netherlands; 2009. p. 3-18.

10. Gurung N, Ray S, Bose S, Rai V. A broader view: microbial enzymes and thei relevance in industries, medicine, and beyond. Biomed Res Int. 2013;2013: 329121.

11. Uthumporn U, Shariffa YN, Karim AA. Hydrolysis of native and heat-treated starches at sub-gelatinization temperature using granular starch hydrolyzing enzyme. Appl Biochem Biotechnol. 2012;166:1167-82.

12. Vihinen M, Mantsala P. Microbial amylolytic enzymes. Crit Rev Biochem Mol Biol. 1989;24:329-418.

13. Janeček Š, Ševčík J. The evolution of starch-binding domain. FEBS Lett. 1999; 456:119-25.

14. Janeček S, Svensson B, MacGregor EA. alpha-Amylase: an enzyme specificity found in various families of glycoside hydrolases. Cell Mol Life Sci. 2014;71: 1149-70.

15. van Zyl WH, Bloom M, Viktor MJ. Engineering yeasts for raw starch conversion. Appl Microbiol Biotechnol. 2012;95:1377-88.

16. Kasana RC, Gulati A. Cellulases from psychrophilic microorganisms: a review. J Basic Microbiol. 2011;51:572-9.
17. Garsoux G, Lamotte J, Gerday C, Feller G. Kinetic and structural optimization to catalysis at low temperatures in a psychrophilic cellulase from the Antarctic bacterium Pseudoalteromonas haloplanktis. Biochem J. 2004;384: 247-53.

18. Gaudin C, Belaich A, Champ S, Belaich JP. CelE, a multidomain cellulase from Clostridium cellulolyticum: a key enzyme in the cellulosome? Jacteriol. 2000;182:1910-5.

19. Singh A, Hayashi K. Microbial cellulases: protein architecture, molecular properties, and biosynthesis. Adv Appl Microbiol. 1995;40:1-44.

20. Kádár Z, Szengyel Z, Réczey K. Simultaneous saccharification and fermentation (SSF) of industrial wastes for the production of ethanol. Ind Crop Prod. 2004;20:103-10.

21. Zeng $R$, Xiong $P$, Wen J. Characterization and gene cloning of a cold-active cellulase from a deep-sea psychrotrophic bacterium Pseudoalteromonas sp. DY3. Extremophiles. 2006:10:79-82

22. Saitoh S, Tanaka T, Kondo A. Co-fermentation of cellulose/xylan using engineered industrial yeast strain OC-2 displaying both beta-glucosidase and beta-xylosidase. Appl Microbiol Biotechnol. 2011;91:1553-9.

23. Yingling B, Li C, Honglin W, Xiwen Y, Zongcheng Y. Multi-objective optimization of bioethanol production during cold enzyme starch hydrolysis in very high gravity cassava mash. Bioresour Technol. 2011;102:8077-84.

24. Marques PT, Pérégo C, Le MJF, Borsali R, Soldi V. Study of gelatinization process and viscoelastic properties of cassava starch: Effect of sodium hydroxide and ethylene glycol diacrylate as cross-linking agent. Carbohydr Polym. 2006;66:396-407.

25. Rahman MS. CRC press; 2008.

26. Carrasco M, Rozas JM, Barahona S, Alcaino J, Cifuentes V, Baeza M. Diversity and extracellular enzymatic activities of yeasts isolated from King George Island, the sub-Antarctic region. BMC Microbiol. 2012;12:251.

27. Salmon DN, Spier MR, Soccol CR, Vandenberghe LP, Weingartner Montibeller V, Bier MC, et al. Analysis of inducers of xylanase and cellulase activities production by Ganoderma applanatum LPB MR-56. Fungal Biol. 2014; 118:655-62.

28. Pascon RC, Bergamo RF, Spinelli RX, de Souza ED, Assis DM, Juliano L, et al. Amylolytic microorganism from Sao Paulo zoo composting: isolation, identification, and amylase production. Enzyme Res. 2011:2011:679624.

29. de Groot PWJ, Brandt BW, Horiuchi H, Ram AFJ, de Koster CG, Klis FM. Comprehensive genomic analysis of cell wall genes in Aspergillus nidulans. Fungal Genet Biol. 2009;46:572-81.

30. van der Kaaii RM, Yuan XL, Franken A, Ram AF, Punt PJ, van der Maarel MJ, et al. Two novel, putatively cell wall-associated and glycosylphosphatidylinositolanchored alpha-glucanotransferase enzymes of Aspergillus niger. Eukaryot Cell. 2007:6:1178-88.

31. Iefuji $\mathrm{H}$, limura $\mathrm{Y}$, Obata T. Isolation and characterization of a yeast sp. S-2 that produces Raw starch-digesting -amylase, xylanase, and polygalacturonase. Biosci, biotechnol. Biochem. 1994;58:2261-2.

32. Wanderley KJ, Torres FAG, Moraes LÄMP, Ulhoa CJ. Biochemical characterization of alpha-amylase from the yeast Cryptococcus flavus. FEMS Microbiol Lett. 2004:231:165-9.

33. Galdino AS, Silva RN, Lottermann MT, Alvares AC, de Moraes LM, Torres FA, et al. Biochemical and Structural Characterization of Amy1: An AlphaAmylase from Cryptococcus flavus Expressed in Saccharomyces cerevisiae. Enzyme Res. 2011:2011:157294.

34. Tsuji M, Singh SM, Yokota Y, Kudoh S, Hoshino T. Influence of initial pH on ethanol production by the Antarctic basidiomycetous yeast Mrakia blollopis. Biosci Biotechnol Biochem. 2013;77:2483-5.

35. Singh $P$, Singh SM, Tsuji M, Prasad GS, Hoshino T. Rhodotorula svalbardensis sp. nov., a novel yeast species isolated from cryoconite holes of Ny-Alesund, Arctic. Cryobiology. 2014;68:122-8.

36. Abdullah SK. Extracellular enzymatic activity of aquatic and aero-aquatic conidial fungi. Hydrobiologia. 1989;174:217-23.

37. Gomes FC, Safar SV, Marques AR, Medeiros AO, Santos AR, Carvalho C, et al. The diversity and extracellular enzymatic activities of yeasts isolated from water tanks of Vriesea minarum, an endangered bromeliad species in Brazil, and the description of Occultifur brasiliensis f.a., sp. nov. Antonie Van Leeuwenhoek. 2015:107:597-611.

38. Pathan AA, Bhadra B, Begum Z, Shivaji S. Diversity of yeasts from puddles in the vicinity of midre lovenbreen glacier, arctic and bioprospecting for enzymes and fatty acids. Curr Microbiol. 2010;60:307-14.

39. Horowitz NH, Cameron RE, Hubbard JS. Microbiology of the dry valleys of Antarctica. Adv Sci. 1972;176:242-5. 
40. Convey P. The influence of environmental characteristics on life history attributes of Antarctic terrestrial biota. Biol Rev. 1996;71:191-225.

41. Arnold RJ, Convey P, Hughes KA, Wynn-Williams DD. Seasonal periodicity of physical factors, inorganic nutrients and microalgae in Antarctic fellfields. Polar Biol. 2003;26:396-403.

42. Juturu V, Wu JC. Microbial cellulases: engineering, production and applications. Renewable Sustainable Energy Rev. 2014;33:188-203.

43. Sharma A, Satyanarayana T. Microbial acid-stable a-amylases: characteristics, genetic engineering and applications. Process Biochem. 2013;48:201-11.

44. Cobos R, Barreiro C, Mateos RM, Juan-Jose R. Cytoplasmic-and extracellularproteome analysis of Diplodia seriata: a phytopathogenic fungus involved in grapevine decline. Proteome Sci. 2010;8:46.

45. Durham HE. A simple method for demonstrating the production of gas by bacteria. Br Med J. 1898;1:1387.

46. Hankin L, Anagnostakis SL. The use of solid media for detection of enzyme production by fungi. Mycologia. 1975;67:597-607.

47. Teather RM, Wood PJ. Use of Congo red-polysaccharide interactions in enumeration and characterization of cellulolytic bacteria from the bovine rumen. Appl Environ Microbiol. 1982;43:777.

48. Shevchenko A, Jensen ON, Podtelejnikov AV, Sagliocco F, Wilm M, Vorm O, et al. Linking genome and proteome by mass spectrometry: large-scale identification of yeast proteins from two dimensional gels. Proc Natl Acad Sci U S A. 1996;93:14440-5.

49. Perkins DN, Pappin DJ, Creasy DM, Cottrell JS. Probability-based protein identification by searching sequence databases using mass spectrometry data. Electrophoresis. 1999;20:3551-67.

Submit your next manuscript to BioMed Central and we will help you at every step:

- We accept pre-submission inquiries

- Our selector tool helps you to find the most relevant journal

- We provide round the clock customer support

- Convenient online submission

- Thorough peer review

- Inclusion in PubMed and all major indexing services

- Maximum visibility for your research

Submit your manuscript at www biomedcentral.com/submit
() BioMed Central 